\title{
A QUALITATIVE STUDY ON ORCHESTRATOR ROLE OF THIRD PARTY LOGISTICS PROVIDERS
}

\author{
EZGI UZEL (1), TUNCAY KOCAMAZ(2)
}

\begin{abstract}
Third party logistics service providers (3PLs) have an important role in logistics triad, and supply chain collaboration. However, there is a lack in marketing literature about their consideration as one of the natural parties of the supply chain. Indeed, related with their firm sizes, firm tenures and their service offerings in recent years, they have become to act as the orchestrators of the supply chain.

This study aims to prove the orchestrator role of 3PLs in Turkey by stating their standardization, visibility and neutral arbitration roles between suppliers and producers. In-dept interviews were conducted on eight logistics professionals consisting both practitioners and academics of logistics in order to create a scale to understand the changing role of 3PLs in Turkey. The results showed that the 3PLs in Turkey have reached to an improved role as the orchestrators of the supply chain.
\end{abstract}

Keywords: Orchestrator role of third party logistics service providers, logistics triad, service advantage, services marketing.

JEL Codes: L91, M16, M31, R41

Öz

Üçüncü parti lojistik hizmet sağlayıcıların (3PL), tedarikçi, üretici ve lojistik hizmet sağlayıcılardan oluşan üçlü lojistik ilişkisinde (logistis triad) önemli bir rolü bulunmaktadır. Ancak pazarlama yazınında üçüncü parti lojistik hizmet sağlayıcıların (3PL) tedarik zincirinin doğal bir öğesi olduğu konusunun yadsındığı görülmektedir. Oysa ki, son yıllarda firma büyüklükleri, görev süreleri ve sundukları hizmetler göz önüne alındığında üçüncü parti lojistik hizmet sağlayıcıların daha gelişmiş bir role (orchestrator role) büründükleri gözlemlenmektedir.

Bu çalışmanın amacı Türkiyede bulunan üçüncü parti lojistik hizmet sağlayıcıların (3PL)

1 Yrd.Doç.Dr., Beykoz Lojistik Meslek Yüksekokulu, ezgiuzel@beykoz.edu.tr

2 Prof. Dr., Yeditepe University, tkocamaz@yeditepe.edu.tr 
standardizasyonu, şeffaflığı ve nötr aracı kurum olma durumlarını tespit ederek gelişmiş bir rol (orchestrator role) edindiklerini göstermektir. Bu değişen rolü açıklamak amacıyla lojistik alanında sekiz profesyonelle derinlemesine mülakatlar yapılmıştır. Sonuçlar, Türkiye'de bulunan üçüncü parti lojistik hizmet sağlayıcıların (3PL), son yıllarda tedarik zincirinde gelişmiş bir role (orchestrator role) eriştiklerini göstermiştir.

Anahtar kelimeler: üçüncü parti lojistik hizmet sağlayıcıların orkestrator rolü, tedarik zincirinde işbirliği, üçlü lojistik ilişki, hizmet avantajı ve hizmet pazarlaması.

JEL Kodları: L91, M16, M31, R41 


\section{Introduction}

Logistics is one of the most important functions in supply chain management, and it has traditionally been considered necessary for connecting production and consumption. However, for most firms, logistics activities have been considered as generator of costs with no capacity for differentiation (Ballou, 2004). This began to change in the mid-1990s as logistics research based on marketing principles began to analyze the capacity of logistics to deliver quality and thus generate greater customer satisfaction (Mentzer, 2004). This change resulted in outsourcing logistics services from third party logistics providers.

In the past, third party logistics providers were only capable and responsible for providing basic logistics services, such as transportation and warehouse management. However, today's customers expect to get much more value-added services from their logistics providers. The value of outsourcing logistics services from logistics service providers has become more common, and proved to be the best way of sustaining competitive advantage in the market.

The needs for focusing on core competencies, reducing logistics costs, and creating a network directed firms to use logistics service providers more often. This change in demand converted the basic role of third party logistics providers to a more advanced role. This orchestrator role is caused by three advantages that are provided by third party logistics providers. The first is; according to transaction cost theory, third party logistics providers are more cost efficient in producing logistics services. The second is; according to resource based theory, third party logistics providers can offer wide range of resources to their customers. Finally; according to network theory, third party logistics service providers can offer great network interactions due to their close relationships with other supply chain partners.

As indicated in the study of Zacharia et al. (2011), third party logistics service providers wore the role as orchestrators of the supply chain by acting as a bridge between the parties by offering standardization, visibility, and neutral arbitration, and collaboration.

This study aims to capture the evolving role of third party logistics providers in Turkey, to prove that they play an orchestrator role within the supply chain. In order to achieve this objective, the first three of the variables (standardization, visibility and neutral arbitrator) that are offered by Zacharia et al. (2011) are explored on Turkish logistics firms to see if they retrieve the orchestrator role in their supply chain.

In depth interview method was used for answering some research questions as indicated below: 
- Do 3PLs of Turkey conduct standardization in their technical and operational procedures?

- Do 3PLs of Turkey conduct visibility in their operational procedures?

- Are 3PLs of Turkey neutral arbitrators of the supply chain?

The importance of this study is that the orchestrator role of third party logistics providers of Turkey within the supply chain has not discussed much in marketing, logistics and supply chain literature. This study reviews the evolving role of logistics service providers in Turkey, and also explains their current advanced role as orchestrators of the supply chain.

\section{Literature Review}

\section{a. Logistics and third party logitics service providers in Turkey}

Logistics sector is based on all transportation activities including airlines and airfreight, shipping, road and rail transport and related infrastructure and services. According to Turkey Logistics Industry Survey 2008, the size of Turkish transportation \& logistics industry is determined as US\$ 59 billion, while the share of the logistics service supplier market is estimated as US\$ 22 billion. Since 2002, the logistics sector has tripled in Turkey which resulted with an unexpected growth potential for logistics service companies. As of 2012, logistics sector has experienced a 12.2\% growth rate in Turkey (Deloitte, 2010). The industry has grown by $20 \%$ on average in the last 5 years and the forecast size is US\$ 120 billion in 2015.

Turkish logistics companies have recognized the opportunities, and started to work on the subject in order to adapt themselves to this new market conditions, and become capable to sustain the recent growth of the sector (Aktas et. al., 2011). The improved logistics performance of Turkey depends on increased export and import volume of the country in recent years which results with growth in number of logistics service providers.

The current trend of logistics service providers is expected to continue paralel to the logistics industry's forecasted growth rate which is US\$ 120 billion by 2015 . The logistics sector in Turkey has been growing and will continue to grow. Turkey has great market potential compared to other countries in the region. It is at the center of trade relations. Due to its geographical advantage, it has the power to connect its neighbour countries, such as Bulgaria, Greece, Ukraine, Russia, Georgia, Armenia, Iraq, Iran and Syria, by offering transfer infrastructure to both goods and passenger traffic (Ovalı, 2008). This improves the logistics infrastructure of the country, and provides opportunity to increase its market potential in the region.

As a result, intermodal freight transportation will be increased, and this will require more logistics service providers. The competition among logistics service providers will switch 
from price competition to service quality. Firms prefer to focus on their core competencies and outsource many kinds of logistics services. They understand the importance of building long-term relationships with the logistics service providers. In order to be successful, logistics service providers in Turkey should be aware of all these developments and get ready for the future.

\section{b. Logistics triad and the orchestrator role of third party logistics providers}

It is found that firms should have an efficient and effective logistics management in order to provide value-added services to their customers. As a result, using third party logistics service providers has increased in recent years, and is expected to increase in the future. It is ranked as one of the young and emerging industries (Kuglin, 1998; Sink, 1996; Sink and Langley, 1997).

In the past, especially traditionally managed firms perceived the logistics activities as they were just supportive functions of their core business. Also, it was thought that third party logistics providers were only capable and responsible for providing basic logistics services, such as transportation and warehouse management. However, today's customers see logistics function as one of the critical functions of a firm that creates value for their supply chains and maintain their competitive advantage againts their rivals. Moreover, the relationships in supply chains have shifted from a dyadic format to a triadic format due to expanded network caused by global trade including suppliers, buyers and finally third party logistics service providers. Beier (1989) called it as "logistics triad" consisting of shipper, carrier and receiver. Gentry (1996), was may be the first one who recognized the linkage between suppliers, purchasing firms and the transportation providers. Larson and Gammelgard (2001) explained the triadic relationship in logistics as the buyer of the goods, the seller of these goods, and the logistics service provider which is between them. Bask (2001) claimed the term third party logistics provider as it is founded in a triadic relationship consists of buyer, supplier and third party logistics provider.

As a result, the change in demand converted the basic role of third party logistics providers to a more advanced role, as orchestrators within the supply chain (Zacharia et al., 2011).

\section{c. The orchestrator role of third party logistics providers within the supply chain}

Orchestration has been discussed in the literature by several researchers. Bitran (2006) advocated that supply chains can only be successful if they are managed by an orchestrator, and defined the orchestrator as it is a neutral party who focuses on developing a system architecture. Stubbs (2004) discussed that third party logistics providers are the type of "hub" firms that emerge as orchestrators in logistics dominant supply chains. 
Christopher (2005) has defined orchestration as it is the activity of managing, coordinating, and focusing the value-creation network. Fulconis (2006) supported the rise of third party logistics providers as the orchestrators of the supply chain by orginizing the supply chain network.

Today's third party logistics providers perform diverse actitivies that create value within the supply chain, such as organizing network, sharing information, managing assets and reducing inventory. All these practises made the third party logistics providers the orchestrators of the supply chain (Zacharia et al., 2011).

Based on Fulconis' (2006) offerings for characteristics of a third party logistics service provider orchestrator firm, Zacharia et al. (2011) offered four factors that characterize a third party logistics provider as an orchestrator which are stardardization, visibility, neutral arbitration and collaboration. According to them third party logistics service providers have been one of the parties in logistics triad which can manage the relationships by standardizing their processes, provide visibility to buyers and sellers, and act as a neutral party to work for benefits of each party in the chain. Finally, by providing all these three variables efficiently (standardization, visibility and neutral arbitration), third party logistics service providers are the ones which can facilitate collaboration within the supply chain much more succcessfully than a supplier or a buyer.

\section{i) Standardization}

Cargill (1989) is one of the most cited researchers about standardization in the literature due to being the writer of the first book "Information Technology Standardization: Theory, Process, and Organizations" on standards. He offered three dimensions about standards. First is determining the measure of "to whom" the standard is important; second is classifying the standarts for "how to" implement them; and lastly referring to a solution, either for a product or a process, by using standards.

Russel (2005) defined standardization as the process of developing and implementing technical standards. De Vries (1999) mentioned the same aim of standardization which creates specificiations that are distributed widely. In the context of customer service, standardization refers to the process of developing an international standard that enables organizations to focus on delivering excellence in customer service. According to social sciences literature, standardization aims to solve coordination problems by recognition of mutual benefits of all parties, and making mutually consistent decisions.

In supply chain management, standardization means the understanding of commonality for parts, processes, products or procurement. Standardization makes the supply chain flows much more smoothly, and the activities become more predictable (Morash and 
Clinton, 1997). Individual processes, organizational entities, and personnel can act more efficiently in terms of less risk, time, labor costs, equipment, or other supply chain resources.

\section{ii) Visibility}

Due to the increase in global sourcing, the supply chains have become much more complex. In order to manage these complex supply chains, information-sharing among the members of the supply chain has become a mandatory factor. Information-sharing helps to match the supply and demand in supply chain network by reducing uncertainty and removing the bull-whip effect (Lee et al., 1997). Simatupang and Sridharan (2002) suggested that supply chain visibility is an important element in improving the global supply chain performance. Indeed, according to Barratt and Oke (2007), performance of a firm is related to visibility factor, and visibility can only be created if the information shared is accurate, timely and useful.

Swaminathan and Tayur (2003) defined visibility as the "ability to access/share information across the supply chain". Mohr and Spekman (1994) defined information visibility in a supply chain as it is the level to which the members of the supply chain have information related to demand and supply for planning and control management.

In the literature, measurement of visibility is usually based on the amount and quality of the accurate, timely and useful information (Barratt and Oke, 2007). According to Tse, Kai and Kim (2012), visibility is the traceability and transparency of supply chain process. Lyles (2008) defined traceability as it is the process for supplier to control the activities from origin to downstream. On the other hand, Christopher and Lee (2004) defined visibility as it is the same thing with transparency. Veronneau and Roy (2009) also used the terms visibility and transparency interchangebly, and said that traceability creates visibility or transparency in supply chains.

Visibility is not the responsibility of one party in the supply chain. In fact, it should be based on an agreement of all members of the supply chain (Skilton and Robinson, 2009). However, due to safety and security or confidentiality issues, most of the focal firms are reluctant to share their information with suppliers or third party logistics service providers (Sahin et al., 2007).

\section{iii) Neutral arbitration}

The concept of neutral arbitration was used by Zacharia et al. (2011) for third party logistics service providers to describe neutral role in the supply chain. According to findings of their study, the users of third party logistics service providers mentioned below ideas 
about neutral arbitrator role of their third party logistics service providers:

- As a user, they can easily share information more than they do with any other party.

- As a user, they believe that their third party logistics service providers share any opportunity they perceive in the market.

- As a user, they believe the industrial experience of their third party logistics service provider so they listen their recommendations.

- As a user, they believe that their third party logistics service provider acts as a change agent and helps in their process during change.

- As a user, they believe that their third party logistics service provider works to create more efficient work processes.

\section{Methodology}

In this study, a qualitative study was conducted to discover the variables about the orchestrator role of 3PLs based of Zacharia et al. (2011) research. The sample was identified, then in-depth interviews were conducted on eight respondents in order to verify the orchestrator role of 3PLs in Turkey. The content analysis was applied on the data. Standardization, visibility and neutral arbitration were found applicable for measuring the orchestrator role of 3PL.

\section{a. Qualitative Study: Sample and Procedures}

In-depth interviews were conducted on logistics professionals in order to discover their perspectives on orchestrator role of 3PLs. Eight logistics professionals were selected from logistics companies, universities and logistics sector associations in order to have a wide range of perspectives. The database of UND (International Transport Association of Turkey) and UTIKAD (Association of International Forwarding and Logistics Service Providers) were used when selecting the respondents from logistics companies. Academics were chosen from logistics departments of universities. Covenience sampling method was used due to time constraints. Finally, the sample consisted one fleet director, one sales manager, one operations manager, one CEO from a logistics company, two logistics academics from logistics department of different universities, one board member from a logistics company, and one respresentative of a non-profit logistics organization.

Eight interviews were conducted. All interviews were audio-taped and transcribed, and lasted from approximately 30 to 50 minutes.

During the interviews, questions were directed to the participants in order to learn what they understood by orchestrator role of standardization, visibility and neutral arbitration. 
The goal was to compare the views of Turkish logistics professionals with the findings of Zacharia et al.'s study on the orchestration role of 3PLs.

\section{b. Qualitative Study: Content Analysis}

After transcription of the interviews, and the organization of the data, four stages of content analysis were followed in this study (Yildirim and Simsek, 2011). In the first stage, the collected data is reviewed and divided into meaningful pieces. Then these meaningful pieces are identified in conceptual basis. After it is determined that these pieces consist a significant form within its context, codes are assigned to these words.

After coding, the second stage of content analysis is categorizing. In order to create categories, the codes are reviewed and determined the similarities and differences between them. Then the ones which are similar to and have relationships with each other are categorized under the same category.

In the the third stage, the data is organized according to the codes and categories. In this part, the relationships between themes and concepts are analyzed, and an objective presentation is prepared. In the final stage, findings are interpreted and the report is written. Figure 1 shows the stages of the content analysis for this study.

The unit of analysis is the "words" used in the interview text. The findings are based on three questions: what do logistics professionals understand by standardization, what do logistics professionals understand by visibility of 3PLS, and what do logistics professionals understand by neutral arbitrator role of 3PLs. Firstly, the words used by the respondents are taken into hand individually, and a word-frequency count is made. Then the most repeated words are assigned to codes, and classified under categories and themes.

\section{c. Qualitative Study: Key Findings}

Firstly, the words used by the respondents are taken into hand individually, and a wordfrequency count is made. Then the most repeated words are assigned to codes, and classified under categories and themes. 
Figure 1:

Stages of content analysis

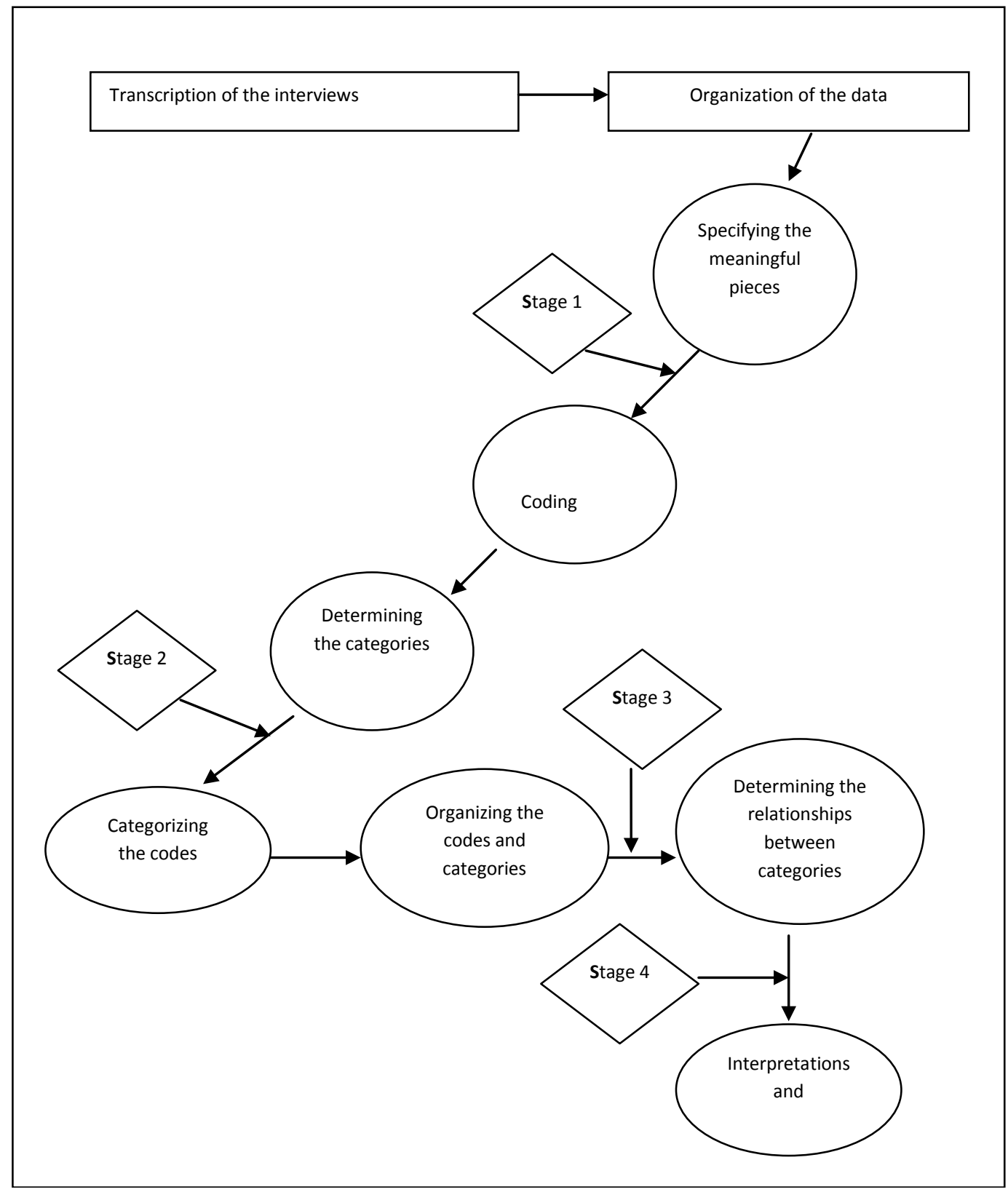




\section{Standardization}

All interviews started with the same question, "What do you understand by standardization in logistics sector", then the respondent left free to continue talk about the subject. The interviewer sometimes probed the answers of the respondent by asking "Why do you say that?", "Can you please explain this in detail?", and "Anything else you want to add?". Probing is important in discovering the hidden ideas of respondents (Malhotra, 2007).

Most of the answers were similar even the positions respondents were different in their companies. They repeated same words which were given in Table 1.

Table 1:

Word counting table for standardization

\begin{tabular}{|l|l|c|}
\hline \multicolumn{1}{|c|}{$\begin{array}{c}\text { Words repeated about } \\
\text { "standardization"? }\end{array}$} & \multicolumn{1}{c|}{$\begin{array}{c}\text { Who pronounced the } \\
\text { word ? }\end{array}$} & $\begin{array}{c}\text { How many times } \\
\text { repeated? }\end{array}$ \\
\hline Shipments & Respondent 1,2,3,4,5,6,7,8 & 618 \\
\hline System & Respondent 1,2,3,4,5,6,7,8 & 532 \\
\hline Process & Respondent 1,2,3,4,5,6,7,8 & 428 \\
\hline Written Procedures & Respondent 1,2,3,4,5,6,7,8 & 357 \\
\hline Operations & Respondent 1,2,3,4,5,6,7,8 & 355 \\
\hline Orders & Respondent 1,2,3,4,5,6,7,8 & 287 \\
\hline Employees / Training & Respondent 1,2,3,5,6,7 & 225 \\
\hline Trucks & Respondent 1,2,3 & 212 \\
\hline Communication & Respondent 1,2,3,4,5,6,7,8 & 188 \\
\hline IT & Respondent 1,2,3,8 & 179 \\
\hline Tracking & Respondent 1,2,3,4 & 178 \\
\hline Warehouse & Respondent 1,2,3 & 154 \\
\hline Regulations & Respondent 1,2,3,4 & 145 \\
\hline Office & Respondent 1,2,3,6,8 & 112 \\
\hline Computer & Respondent 1,2,3,4,5,6,7,8 & 110 \\
\hline Network & Respondent 2,4,5,6,7,8 & 82 \\
\hline Software & Respondent 1,2,3,4 & 74 \\
\hline Equipments & Respondent 1,3 & 55 \\
\hline
\end{tabular}

Striking ideas were derived from the answers of the respondents to develop items for the questionnaire. As it is shown in above table, having written operational procedures is one of most repeated terms about standardization. Technical standards, such as compatibility of trucks, equipments used in the company and warehouse systems can be accumulated, 
and assumed to be at the second place which was related with standardization. Five out of eight respondents shared the same idea about having the right personnel to apply these procedures in the company. They repeated personnel training and importance of human resource department in companies. Finally, all respondents were aware of the need for investments in technology and encouraged their companies to make investments for setting standardization. The words sofware systems, CRM and network were repeated several times to underline the importance of technological investments.

Ideas of some of the respondents were given as below:

Respondent 1, fleet director of one of the biggest logistics company of Turkey, shared his ideas about compatibility of their trucks as below:

\footnotetext{
"Compatibility of trucks are very important today. Especially, for the companies which operate to and from EU countries. The regulations are administered strictly, and we have to obey them. But also, our company really cares about low $\mathrm{CO} 2$ emmision. In my belief, technical standards of our company make our customers trust us".
}

Respondent 2, sales manager of one reputable logistics company talked about their standard operations process:

"We have spent too much time on developing these written procedures. This was a 'must' for handling the customers equally. The job should not be depended on one specific person. Everybody should be capable of doing each others' jobs by checking these written procedures. Even we deliver these written procedures to our interns in order to adapt them to our system."

So, "standardization" that derived from literature is directly assigned as the first theme. According to answers of the respondents, it can be summated under three categories which are technical standardization, standardization in procedures and standardization of the personnel. Then the codes are delivered under these three categories. Table 2 shows the results as below: 
Table 2:

Themes and Codes for Standardization

\begin{tabular}{|c|c|c|c|}
\hline Theme & & Standardization & \\
\hline Categories & technical standardization & $\begin{array}{l}\text { written work } \\
\text { process }\end{array}$ & personnel \\
\hline Codes & $\begin{array}{l}\text { - } \begin{array}{l}\text { compatibility of the } \\
\text { trucks to regulations }\end{array} \\
\text { - } \begin{array}{l}\text { technical equipments } \\
\text { (including forklifts, } \\
\text { shelf systems etc...) }\end{array} \\
\text { - } \text { software systems } \\
\text { customer relationship } \\
\text { managemet (CRM) } \\
\text { warehouse system }\end{array}$ & $\begin{array}{l}\text { - } \begin{array}{l}\text { written } \\
\text { procedures }\end{array} \\
\text { standard } \\
\text { operational } \\
\text { procedure } \\
\text { (SOP) } \\
\text { definition of } \\
\text { activities } \\
\text { filing and } \\
\text { archieve }\end{array}$ & $\begin{array}{l}\text { - } \quad \text { personnel training } \\
\text { - } \text { human resources } \\
\text { department } \\
\text { - } \text { responsiveness } \\
\text { discipline }\end{array}$ \\
\hline
\end{tabular}

The results about standardization were found similar with the findings of Zacharia et al. (2011). They mentioned the importance of standardization on data, processes and technology (p.48) which supported with the answers of the respondents of this study.

\section{Visibility}

After getting the answers about standardization, the next question of the interview was, "What do you understand by the visibility of 3PLs?". The respondents repeated the words given below: 
Table 3:

Word Counting for Visibility

\begin{tabular}{|l|l|c|}
\hline $\begin{array}{c}\text { Words repeated about } \\
\text { "visibility"? }\end{array}$ & Who pronounced the word ? & $\begin{array}{c}\text { How many times } \\
\text { repeated? }\end{array}$ \\
\hline Customer & Respondent 1,2,3,4,5,6,7,8 & 855 \\
\hline Communication & Respondent 1,2,3,4,5,6,7,8 & 745 \\
\hline Information Sharing & Respondent 1,2,3,4,5,6,7,8 & 728 \\
\hline Technology & Respondent 1,2,3,4,5,6,7,8 & 692 \\
\hline Timeliness & Respondent 1,2,3,4,5,6,7,8 & 613 \\
\hline Truth & Respondent 1,3 & 589 \\
\hline Tracking Orders & Respondent 1,3 & 556 \\
\hline Tracking Shipments & Respondent 1,2,3 & 555 \\
\hline Tracing & Respondent 1,2,3,4,8 & 448 \\
\hline Transparency & Respondent 2,4,5,8 & 344 \\
\hline Telling Lies & Respondent 1,2,3 & 286 \\
\hline Trust & Respondent 1,2,3,6 & 247 \\
\hline Long-Term Relationship & Respondent 1,2,3,4,5,6,7 & 239 \\
\hline Interdependence & Respondent 2,4,5,6,7 & 186 \\
\hline
\end{tabular}

According to respondents, visibility meant sharing of information with customers on time, without lies. "After developments in technology, the capability of companies increased in providing on-time information about shipments, no room for lies!", said the Respondent 1 , the fleet director. Respondent 3, the operations manager also mentioned similar ideas about visibility. He said, "... everything became transparent in warehouses. Whenever we recieve an order, everybody who is related with the process, sees it at the same time, a mistake is seen by every one.."

The respondents related the "visibility" mostly with willingness to share information and being trustful. They were aware that creating long-term relationship is valuable, and hiding information from a customer will destroy this relationship.

So, "visibility" that derived from literature is directly assigned as the second theme. According to answers of the respondents, visibility can be summated under two categories which are visibility about shipments of customers and orders of shipments. Then the codes are delivered under these two categories. Table 4 shows the results as below: 
Table 4:

Themes and Codes for Visibility

\begin{tabular}{|c|c|c|}
\hline Theme & \multicolumn{2}{|c|}{ Visibility } \\
\hline Categories & shipments & orders \\
\hline \multirow{4}{*}{ Codes } & $\begin{array}{l}\text { - sharing information } \\
\text { with customers about } \\
\text { their shipments }\end{array}$ & $\begin{array}{l}\text { - sharing information } \\
\text { with customers about } \\
\text { their orders }\end{array}$ \\
\hline & $\begin{array}{l}\text { - timely information } \\
\text { sharing about the } \\
\text { shipments }\end{array}$ & $\begin{array}{l}\text { timely information } \\
\text { sharing about the } \\
\text { orders }\end{array}$ \\
\hline & $\begin{array}{l}\text { - providing accurate } \\
\text { information about the } \\
\text { shipments }\end{array}$ & $\begin{array}{l}\text { - providing accurate } \\
\text { information about the } \\
\text { orders }\end{array}$ \\
\hline & $\begin{array}{l}\text { - providing up-to-date } \\
\text { information about the } \\
\text { shipments }\end{array}$ & $\begin{array}{l}\text { - providing up-to-date } \\
\text { information about the } \\
\text { orders }\end{array}$ \\
\hline
\end{tabular}

The results about visibility were found similar with the findings of Zacharia, et al. (2011). They mentioned the importance of providing visibility to customers for tracking, tracing and planning their shipments and orders (p.48) which supported with the answers of the respondents of this study.

\section{Neutral arbitration}

The following question of the interview was, "What do you understand by the neutral arbitrator role of 3PLs?". The words used and repeated by the respondents are shown with the following table.

Respondent 1, the fleet director explained how 3PLs of Turkey act as a change leader and how they have expertise in their field with following words:

"One of our textile customers who currently exports from Europe to Turkey announced that they plan to expand their market via Turkey through Middle East countries. But they have little knowledge about this new market. Since we have already had operations to these countries, we know the details about them. Such as legal systems, customs procedures, political issues... We listened their plans carefully. It was surprising that they share very 
confidential information about their company. They are at the threshold of entering a new market, they have several strategic plans, but still they did not hesisate to share them with us. At the end of the day, they appreciated for our expertise. They believe that our efforts will enable their entry to this new market, and make their process much more efficient."

Table 5:

Words Counting for Neutral Arbitration

\begin{tabular}{|l|l|c|}
\hline \multicolumn{1}{|c|}{$\begin{array}{c}\text { Words repeated about } \\
\text { "neutral arbitration" }\end{array}$} & Who pronounced the word? & $\begin{array}{c}\text { How many } \\
\text { times repeated? }\end{array}$ \\
\hline Expertise & Respondent $2,4,5,6,7,8$ & 749 \\
\hline Experience & Respondent $1,3,4,5,6,7$ & 735 \\
\hline Knowledge & Respondent $1,2,3,4,5,6,7,8$ & 698 \\
\hline Position in the Market & Respondent 2,4,5,6,8 & 655 \\
\hline Network & Respondent $2,4,5,6,7,8$ & 635 \\
\hline Adaptability & Respondent $1,2,3,5,6,7$ & 622 \\
\hline Flexibility & Respondent $1,3,4,6,7$ & 615 \\
\hline Recommendations & Respondent $1,2,3,5,6,7$ & 607 \\
\hline Innovativeness & Respondent $1,2,4,5,7$ & 567 \\
\hline Change & Respondent $2,3,4,6,8$ & 543 \\
\hline Mutual Trust & Respondent $1,2,3,4,5,6,7,8$ & 540 \\
\hline Information Sharing & Respondent $1,3,4,5,6,7$ & 535 \\
\hline Opportunities & Respondent $2,4,6$ & 476 \\
\hline Long-Term Relationship & Respondent $1,2,3,4,5,6,7$ & 462 \\
\hline Benefits & Respondent 1,2,3,4,5,6,7 & 457 \\
\hline Objectiveness & Respondent $1,2,3,4,5,6,7,8$ & 365 \\
\hline Intermediaries & Respondent $1,2,3,4,5,6,7$ & 346 \\
\hline & & \\
\hline
\end{tabular}

Another dimension of neutral arbitration was explained with below words by Respondent 8 , the sector respresentative from one of the non-profit organizations;

"The role of logistics companies has evolved rapidly in recent years. As global trade increased, the traffic over Turkey has experienced a growth. I think logistics companies in Turkey adapted themselves to this change successfully. They made smart investments, they expanded their capacities and scope of services provided. This evolving role gives trust to suppliers and producers. Logistics companies of Turkey become a party that makes the relationship 
between the suppliers and producers work more efficiently. Logistics companies remove most of the conflicts between these parties..."

So, "neutral arbitration" that derived from literature is directly assigned as the third theme. According to answers of the respondents, neutral arbitration can be summated under three categories which are sectoral expertise, change leader, and objectiveness. Then the codes are delivered under these three categories. Table 6 shows the results as below:

Table 6:

Themes and Codes for Neutral Arbitration

\begin{tabular}{|c|c|c|c|}
\hline Theme & \multicolumn{3}{|c|}{ Neutral Arbitration } \\
\hline Categories & sectoral expertise & change leader & objectiveness \\
\hline Codes & 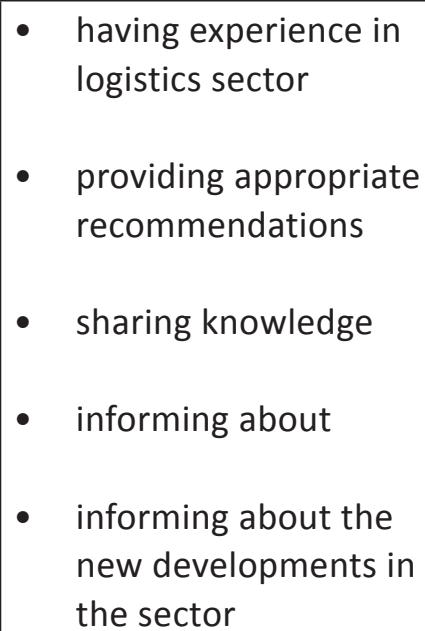 & $\begin{array}{l}\text { - } \begin{array}{l}\text { catching } \\
\text { opportunities } \\
\text { in the market }\end{array} \\
\text { - } \begin{array}{l}\text { providing } \\
\text { flexible work } \\
\text { procedures }\end{array} \\
\text { creating new } \\
\text { markets } \\
\text { taking role in } \\
\text { new projects }\end{array}$ & $\begin{array}{l}\text { - } \text { sharing information } \\
\text { - providing a } \\
\text { consulting service } \\
\text { - playing a neutral } \\
\text { role between the } \\
\text { chain members } \\
\text { - informing about the } \\
\text { opportunities in the } \\
\text { sector without a } \\
\text { benefit }\end{array}$ \\
\hline
\end{tabular}

The results about neutral arbitration were found similar with the findings of Zacharia, et al. (2011). They underlined the role of 3PLs as neutral arbitrators of the supply chain by sharing useful information with parties objectively without expecting a benefit, having sectoral expertise and experience, driving change in the chain by providing new opportunities, and create efficient work processes.

Finally, related research questions were supported with the results of this qualitative study. 
Table 7:

Research Questions

\begin{tabular}{|l|c|}
\hline Main Research Questions & Results \\
\hline $\begin{array}{l}\text { Do 3PLs of Turkey conduct standardization in their technical and } \\
\text { operational procedures? }\end{array}$ & Confirmed \\
\hline Do 3PLs of Turkey conduct visibility in their operational procedures? & Confirmed \\
\hline Are 3PLs of Turkey neutral arbitrators of the supply chain ? & Confirmed \\
\hline
\end{tabular}

\section{d. Content Validity of the Study}

Content validity is a type of validity provides the power of representativeness of the content of the scale (Malhotra, 2007). Content validity of this study was assesed by literature review as it is indicated by Dunn, Seaker and Walker (1994), and the qualitative study conducted with logistics professionals as it is provided in subsection 3(c).

\section{Conclusion}

The main purpose of this study was to examine the orchestrator role of 3PLs in Turkey. The three variables, standardization, visibility and neutral arbitration, for measuring the orchestrator role of 3PLs offered by Zacharia et al. (2011) were adopted, and a qualitative study was conducted in order to see if these variables were applicable on Turkish sample. According to the findings of in-depth interviews with eight logistics professionals, it was observed that these three variables were also found similar to the study of Zacharia et al. (2011) that Turkish logistics service providers have become to be the orchestrators of their supply chain by their technical and administrative standards, visible procedures, and considerations of their customers as the neutral arbitrators in the supply chain.

According to the findings about "standardization", most of the Turkish logistics companies have standard operating procedures in written, and their employees obey the rules of these procedures which eliminates the dependency on individuals. Besides this, the transport vehicles they use are compatible with both Turkish and EU regulations, such as using Euro 5 trucks which eliminates $\mathrm{CO} 2$ emissions. Their warehouses and other buildings are smartly designed for driving time and cost effective operations. Also, it is found that logistis companies in Turkey are open to developments and further improvements, and they have plans for future investments on both infrastructure and technology.

For the "visibility", it can be said that the logistics companies of Turkey are visible by their technological infrastructures. All of them provide tracking and tracing services. They can 
easily provide timely, relevant and up-to-date information to their customers. All of them have websites, and customers can have access to tracking and tracing information with their private passwords. On the other hand, 3PLs in Turkey use software programs for internal communication, and if it is required from a customer, they can provide access to their customers externally. Also, it is identified that some of the 3PLs give access to both suppliers and their customers, and receive and deliver information from/to both parties Some of the 3PLs use Electronic Data Exchange (EDI) systems.

For the "neutral arbitration", 3PLs of Turkey act as the bridge between the suppliers and customers which provide efficient information flow between these two, so that they can avoid the conflicts. On the other hand, due to their network capability, they have market knowledge and experience globally which helps their customers in driving change and providing new market opportunities.

By proving these three important characteristics (standardization, visibility and neutral arbitration), it is found that Turkish logistics companies were evolved for years, and they present capability to be the orchestrators of the supply chain.

\section{REFERENCES}

Aktaş, Emel, Berrin Ağaran, Füsun Ülengin and Şule Önsel (2011) "The Use of Outsourcing Logistics Activities: The Case of Turkey", Transportation Research Part C, 39, p.833-852.

Ballau, Ronald H. (2003) Business Logistics / Supply Chain Management, 5th Edition, US: Prentice Hall.

Barratt, Mark and Adegoke Oke (2007) "Antecedents of Supply Chain Visibility in Retail Supply Chains: A Resource-Based Theory Perspective", Journal of Operations Management, 25, p.1217-1233.

Bask, Anu H. (2001) "Relationship among TPL Providers and Members of Supply Chains - A Strategic Perspective", Journal of Business \& Industrial Marketing, 16(6), p.470-86.

Beier, Frederick J. (1989) "Transportation Contracts and the Experience Effect: A Framework for Future Research," Journal of Business Logistics, 10(2), p.73-89.

Bitran, Gabriel R., Suri Gurumurthi and Shiou Lin Sam (2006) Emerging Trends in Supply Chain Governance, SSRN Working Paper Series, New York.

Cargill, Carl F. (1989) Information Technology Standardization: Theory, Process, and Organizations, Digital Press, ISBN 1-5558-022-X. 
Christopher, Martin (2005) Logistics and Supply Chain Management: Creating Value Added Networks, London: Financial Times Prentice Hall.

Christopher, Martin and Hau L. Lee (2004) “Mitigating Supply Chain Risk through Improved Confidence", International Journal of Physical Distribution \& Logistics Management, 34(5), p.388-396.

Fulconis, François, Laurence Saglietto and Gilles Pasche (2006) "Exploring New Competences in the Logistics Industry: The Intermediation Role of 4PL", Supply Chain Forum: An International Journal, 7(2), p.68-72.

Gentry, Julie J. (1996) "Carrier Involvement in Buyer-Supplier Strategic Partnerships," International Journal of Physical Distribution \& Logistics Management, 26(3), p.14-25.

Kuglin, Fred A. (1998) Customer Centered Supply Chain Management, New York: AMACOM.

Larson, Paul D. and Britta Gammelgard (2001-02) "The Logistics Triad: Survey and Case Study Results", Transportation Journal, 41(2-3), p.71-82.

Lee, Hau. L., Paddy Padmanabhan and Seungjing Whang (1997) "Information Distortion in a Supply Chain: The Bullwhip Effect", Management Science, 43, p.546-558.

Lyles, Marjori A., Barbara B. Flynn and Mark T. Frohlich (2008) "All Supply Chains Don't Flow Through: Understanding Supply Chain Issues in Product Recall", Management and Organization Review, 4(2), p.167-182.

Malhotra, Naresh K. (2007) Marketing Research, 5th Edition, New Jersey: Pearson Education.

Mentzer, John T. (2004) Fundamentals of Supply Chain Management: Twelve Drivers for Competitive Advantage, California: Sage.

Mohr, Jakki, and Robert E. Spekman (1994) "Characteristics of Partnership Success: Partnership Attributes, Communication Behaviour, and Conflict Resolution Techniques", Strategic Management Journal, 15(2), p.135-152.

Morash, Edward A., and Clinton, Steven R. (1997) “The Role of Transportation Capabilities in International Supply Chain Management", Transportation Journal, 36(3), p.5-17.

Ovalı, Serap (2008) "TRACECA Projesi ve Türkiye", International Journal of Economic and Administrative Studies, 1(1), p.151-170. 
Russell, Andrew L. (2005) "Standardization in History: A Review Essay with an Eye to the Future", in The Standards Edge: Future Generations (eds. S. Bolin and A. Arbor), US: Sheridan. p.247-260.

Şahin, Evren, Mohamed Zied Babai, Yves Dallery and Renaud Vaillant (2007) "Ensuring Supply Chain Safety Through Time Temperature Integrators", The International Journal of Logistics Management, 18(1), p.102-124.

Simatupang, Togar M. and Sridharan, R. (2002) "The Collaborative Supply Chain", International Journal of Logistics Management, 13(1), p.15-30.

Sink, Harry L. and C. John Langley Jr. (1997) “A Managerial Framework for the Acquisition of Third-Party Logistics Services", Journal of Business Logistics, 18(2), p.163-189.

Sink, Harry L., C. John Langley Jr. and Brian J. Gibson (1996) "Buyer Observations of The US Third-party Logistics Market", International Journal of Physical Distributions, 26(3), p.38-46.

Skilton, Paul F. and Jessica L. Robinson (2009) "Traceability And Normal Accident Theory: How Does Supply Network Complexity Influence The Traceability Of Adverse Events?", Journal of Supply Chain Management, 45(3), p.40-53.

Stubbs, Charles (2004) "Partnering in the New Economy", European Business Journal, 16(3), p.113-19.

Swaminathan, Jayashankar M. and Sridhar R. Tayur (2003) "Models For Supply Chain in E-Business", Journal of Management Science, 49(10), p.1387-1406.

Tse, Ying Kei and Kim Hua Tan (2012) "Managing Product Quality Risk and Visibility in Multi-Layer Supply Chain", International Journal of Production Economics, 139(1), p.4957.

Veronneau, Simon and Jacques Roy (2009) "RFID Benefits, Costs, and Possibilities: The Economical Analysis of RFID Deployment in a Cruise Corporation Global Service Supply Chain", International Journal of Production Economics, 122, p.692-702.

Vries, Henk J. de (1999) Standardization - A Business Approach to the Role of National Standardization Organizations, Boston: Kluwer Academic.

Yıldırım, Ali and Hakan Şimşek (2011) Sosyal Bilimlerde Nitel Araştırma Yöntemleri, 8th edition, Ankara: Seçkin. 
Zacharia, Zach G., Nada R. Sanders and Nancy W. Nix (2011) "The Emerging Role of the Third-Party Logistics Provider (3PL) as an Orchestrator", Journal of Business Logistics, 32(1), p.40-54. 